\title{
Proteinograma e concentração sérica de IgG em potros, do nascimento aos trinta dias de vida, tratados com plasma ${ }^{1}$
}

\author{
Campo A.V.C. Neto ${ }^{2}$, José P. Oliveira-Filho², Diego J.Z. Delfiol ${ }^{3}$, Peres R. Badial ${ }^{4}$, \\ João P. Araújo Júnior ${ }^{5}$, Tais F. Cruz ${ }^{5}$, Michely S. Tenório ${ }^{5}$ e Alexandre S. Borges ${ }^{2 *}$
}

\begin{abstract}
Neto C.A.V.C., Oliveira-Filho J.P., Delfiol D.J.Z., Badial P.R., Araújo Júnior J.P., Cruz T.F., Tenório M.S. \& Borges A.S. 2018. [Proteinogram and serum IgG concentration in newborn foals up to thirty days of life treated with plasma.] Proteinograma e concentração sérica de IgG em potros, do nascimento aos trinta dias de vida, tratados com plasma. Pesquisa Veterinária Brasileira 38(5):795-805. Departamento de Clínica Veterinária, Faculdade de Medicina Veterinária e Zootecnia, Universidade Estadual Paulista, Campus de Botucatu, Botucatu, SP 18618-970, Brazil. E-mail: asborges@fmvz.unesp.br

The aim of this study was to evaluate serum protein and serum IgG concentrations (after a direct enzyme immunoassay test ELISA optimization) in newborns foals from birth to thirty days of life before and after colostrum consumption and intravenous treatment with plasma. Twenty foals and their respective progenitors as well as four plasma donor's horses were used. Blood samples were obtained from newborn foals at five time points, immediately after birth and before colostrum intake (M1), ten hours after birth (M2), 24 hours after birth and prior administration of blood plasma (M3), 48 hours after birth and 24 hours after plasma administration (M4), and 30 days after birth (M5). Blood and colostrum samples were collected from the progenitor mares immediately postpartum. Concentration of total protein (TP) and albumin were determined using a biochemical analyzer. The TP concentration was also measured by refractometer. Fractions of total serum protein were separated using agarose gel electrophoresis. Colostrum density was evaluated using BRIX refractometer and specific density colostrometer. Total IgG concentration was determined by an enzyme-linked immunosorbent assay. With the ELISA system proposed here it was possible to determine IgG concentrations in serum, plasma, and equine colostrum samples with adequate repeatability. Serum IgG concentration in foals at birth was $15 \pm 8 \mathrm{mg} / \mathrm{dL}$ (mean \pm standard deviation) raising at ten hours $(2,408 \pm 608 \mathrm{mg} / \mathrm{dL}$ ) and remaining at similar levels up to 48 hours of life $(2,364 \pm 784 \mathrm{mg} / \mathrm{dL})$, and decreasing significantly at 30 days of age $(1,414 \pm 586 \mathrm{mg} / \mathrm{dL})$. Serum and colostrum IgG concentrations of mares were $1,746 \pm 505 \mathrm{mg} / \mathrm{dL}$ and $7,714 \pm 2,619 \mathrm{mg} / \mathrm{dL}$, respectively. The plasma IgG concentrations from donor mares were $2,026 \pm 148 \mathrm{mg} / \mathrm{dL}$. Total protein, total globulins, and $\gamma$-globulin fraction showed correlation with IgG. Ten hours post birth was an adequate time to verify the transfer of passive immunity, allowing to adoption prophylactic and/or therapeutic measures in a horse farms. One liter of plasma administered at 24 hours of life was not sufficient to raise serum IgG concentrations in foals without passive immunity transfer failure.
\end{abstract}

INDEX TERMS: Proteinogram, IgG, foals, plasma, equine, enzyme immunoassay, electrophoresis, immunoglobulins, proteins.

\footnotetext{
${ }^{1}$ Recebido em 14 de abril de 2017.

Aceito para publicação em 23 de maio de 2017.

${ }^{2}$ Departamento de Clínica Veterinária, Faculdade de Medicina Veterinária e Zootecnia, Universidade Estadual Paulista (Unesp), Campus de Botucatu, SP 18618-970, Brasil.*Autor para correspondência: asborges@fmvz.unesp.br

${ }^{3}$ Faculdade de Medicina Veterinária (FAMEV), Universidade Federal de Uberlândia (UFU), Uberlândia, MG 38405-314, Brasil.

${ }^{4}$ Department of Pathobiology and Population Medicine, College of Veterinary Medicine, Mississippi State University, Mississipi State, MS 39762, USA.

${ }^{5}$ Departamento de Microbiologia e Imunologia, Instituto de Biociência de Botucatu, Universidade Estadual Paulista (Unesp), Botucatu, SP 18618-691.
}

RESUMO.- Este trabalho teve por objetivo avaliar o proteinograma e concentrações séricas de IgG (após a padronização de teste ELISA) em potros do nascimento aos trinta dias de idade, antes e depois de mamarem colostro e serem tratados com plasma por via intravenosa. Foram utilizados 20 potros e suas respectivas mães, além de quatro animais doadores de plasma. Foram colhidas amostras de sangue dos potros em cinco momentos, logo após o nascimento e antes de mamar colostro (M1), dez horas após nascimento (M2), 24 horas 
após nascimento e previamente administração do plasma sanguíneo (M3), 48 horas de vida e 24 horas após administração do plasma sanguíneo (M4), e 30 dias após nascimento (M5). Foram colhidos sangue e colostro das éguas progenitoras no momento do parto. A concentração de proteína total (PT) e albumina foram determinadas em analisador bioquímico, a concentração de PT também foi avaliada em refratômetro manual. $\mathrm{O}$ fracionamento proteico foi realizado utilizando eletroforese em gel de agarose. A densidade do colostro foi avaliada com colostrômetros de refração BRIX e de densidade específica. A concentração de IgG total de todas as amostras foi determinada por teste ELISA. Com o sistema de ELISA aqui proposto foi possível determinar concentrações de IgG em amostras de soro, plasma e colostro equino com adequada repetibilidade. A média \pm desvio padrão da concentração sérica de IgG dos potros ao nascer, foi de $15 \pm 8 \mathrm{mg} / \mathrm{dL}$, com dez horas de vida foi de $2.408 \pm 608 \mathrm{mg} / \mathrm{dL}$, se manteve em níveis semelhantes até 48 horas $(2.364 \pm 784 \mathrm{mg} / \mathrm{dL})$ e diminuíram significativamente aos 30 dias de vida $(1.414 \pm 586 \mathrm{mg} / \mathrm{dL})$. A concentração sérica e colostral de IgG nas éguas foi de $1.746 \pm 505 \mathrm{mg} / \mathrm{dL}$ e $7.714 \pm 2.619 \mathrm{mg} / \mathrm{dL}$, respectivamente. A concentração plasmática de IgG dos doadores de plasma foi de $2.026 \pm 148 \mathrm{mg} / \mathrm{dL}$. Houve correlação positiva entre as concentrações séricas de IgG e PT ( $\mathrm{r}=0,69$ para refratômetro e $\mathrm{r}=0,76$ para bioquímico), GT ( $\mathrm{r}=0,81)$ e gamaglobulina $(\mathrm{r}=0,85)$. Dez horas após o nascimento foi possível verificar a transferência de imunidade passiva, possibilitando adotar medidas profiláticas e/ou terapêuticas em haras de criação de cavalos. Considerando que a proteína total, globulinas totais e fração $\gamma$-globulina apresentam correlação com IgG, estas determinações são úteis para monitorar os potros após mamarem o colostro. Um litro de plasma administrado às 24 horas de vida não foi suficiente para aumentar as concentrações séricas de IgG, 24 horas após transfusão, em potros com adequada transferência de imunidade passiva.

TERMOS DE INDEXAÇÃO: Proteinograma, IgG, potros, plasma, equinos, imunoensaio enzimático, eletroforese, imunoglobulina, proteínas.

\section{INTRODUÇÃO}

Potros são considerados agamaglobulinêmicos ao nascerem devido à placentação epiteliocorial da égua, sendo dependentes da transferência passiva de imunoglobulinas fornecidas pelo colostro (Jeffcott 1974a, LeBlanc et al. 1992). O colostro deve ser ingerido preferencialmente nas primeiras 12 horas de vida, pois a capacidade de absorção de imunoglobulinas reduz significativamente após este período (Jeffcott 1974a, Raidal et al. 2005).

Nível sérico de imunoglobulina G (IgG) total acima de $800 \mathrm{mg} / \mathrm{dL}$, nas primeiras 12 horas de vida, é considerado como transferência de imunidade passiva adequada de anticorpos ao potro, enquanto que valores entre $800-400 \mathrm{mg} / \mathrm{dL}$ e abaixo de $400 \mathrm{mg} / \mathrm{dL}$ são considerados falha de transferência de imunidade passiva (FTIP) parcial e total, respectivamente (Baldwin et al. 1991, McClure et al. 2003). Além disso, alguns autores sugerem que ocorre FTIP em potros quando a concentração sérica de PT for menor que $4.800 \mathrm{mg} / \mathrm{dL}$ (Metzger et al. 2006) ou globulina total sérica menor que $2.230 \mathrm{mg} / \mathrm{dL}$ (Hurcombe et al. 2012) ou $\gamma$-globulinas inferiores a $800 \mathrm{mg} / \mathrm{dL}$ (Fouché et al. 2014).
A prevalência de FTIP varia de $16 \%$ a $37,8 \%$ (Tyler-mcgowan et al. 1997, Mcclure et al. 2003). Potros com FTIP apresentam alta susceptibilidade às enfermidades infecciosas (Clabough et al. 1991), estudos epidemiológicos demostram que até $74 \%$ dos potros com FTIP podem vir a óbito (Haas et al. 1996). No Brasil, as taxas de FTIP em neonatos bovinos estão bem estabelecidas (Costa et al. 2008, Gasparelli et al. 2009, Feitosa et al. 2010), todavia pouco se sabe sobre índices de FTIP em rebanhos equinos (Scotoni \& Machado Neto 1991, Lang et al. 2007). A recomendação geral é que potros com FTIP devem ser suplementados com colostro (Hofsaess 2001) e/ou com plasma hiperimune por via intravenosa (Higuchi et al. 1999, Caston et al. 2006, Giguère et al. 2002).

A imunodifusão radial simples (IDRS) é um método direto para detectar a concentração de IgG total e é considerada a técnica "padrão ouro" (LeBlanc et al. 1986, Giguère et al. 2002, Lang et al. 2007). 0 método de ELISA (enzyme-linked immunosorbent assay), também são métodos diretos, altamente sensíveis e específicos, utilizados para detectar concentrações de IgG total (Erhard et al. 2001, Sedlinská et al. 2006), subtipos de IgG (Sheoran et al. 2000) ou IgG antígeno-específicas permitindo a avaliação simultânea de um grande número de amostras (Higuchi et al. 1999, McClure et al. 2001, Martins et al. 2010). Assim, muito útil para avaliação do perfil imunológico pré e pós-vacinal de animais (Davis 2016), além da qualidade de colostro e plasma hiperimune, a fim de estabelecer estratégias de profilaxia, por exemplo, em haras de criação de equinos, onde muitas amostras com concentrações variadas precisam ser corridas em um mesmo teste, o que representa ganho de tempo e redução de custos em análises. Existem ainda testes semiquantitativos rápidos (SNAP test) que são amplamente utilizados internacionalmente para o diagnóstico de FTIP em potros (Pusterla et al. 2002, McClure et al. 2003, Davis \& Giguère 2005). Todavia, estes testes rápidos têm alto custo no mercado nacional, o que dificulta o seu uso à campo ou em estudos de prevalência de FTIP. Além disso, os testes rápidos fornecem resultados com intervalos de detecção $<400 \mathrm{mg} / \mathrm{dL}, 400-800 \mathrm{mg} / \mathrm{dL}$ e $>800 \mathrm{mg} / \mathrm{dL}$ de $\mathrm{IgG}$, o que inviabiliza seu uso para avaliar a variação da concentração de IgG em amostras de soro, plasma ou colostro com valores acima dos $800 \mathrm{mg} / \mathrm{dL}$ (Davis 2016).

Este trabalho teve por objetivo padronizar um método de ELISA para determinar a concentração sérica de IgG e verificar sua correlação com a proteína total e com as frações de proteínas séricas em potros que mamaram o colostro, do nascimento aos trinta dias de idade e que foram tratados com plasma às 24 horas de vida.

\section{MATERIAL E MÉTODOS}

\section{Animais}

Os animais utilizados neste experimento pertenciam a um haras localizado no estado de São Paulo. A realização deste trabalho foi autorizada pelo responsável da propriedade e aprovado pela Comissão de Ética no Uso de Animais (CEUA) da Faculdade de Medicina Veterinária e Zootecnia da Universidade Estadual Paulista FMVZ/UNESP, Campus de Botucatu (protocolo nำ173/2015).

Foram utilizadas 20 éguas da raça Puro Sangue Inglês (PSI) e seus respectivos potros durante uma única estação de nascimentos. Quatro fêmeas adultas, três da raça Bretão e uma da raça Percheron, 
foram utilizadas como doadoras de plasma. Todos os animais foram mantidos sob as mesmas condições de manejo em piquetes com capim Coast-Cross, água à vontade e suplementação com ração e sal mineralizado. Os partos foram assistidos e ocorreram em baias maternidade, as quais foram higienizadas no intervalo entre cada parto. Imediatamente após o parto os potros foram auxiliados no momento de procurar a glândula mamária da mãe para garantir que mamassem o colostro. 0 tempo até se levantar e primeira mamada, bem como peso e altura dos potros, idade e tempo gestacional das éguas foram anotados em fichas individuais.

\section{Imunização das éguas}

As éguas PSI foram vacinadas 45 e 15 dias antes da data prevista para o parto contra Rhodococcus equi ${ }^{6}$, Escherichia coli $^{7}$ Salmonella $^{7} \mathrm{e}$ $\mathrm{Klebsiella}^{7}$. Além destas vacinas, as éguas foram vacinadas, seguindo o calendário normal de imunização do haras no 5ํㅜ 7ํㅜ e 9o meses de prenhez contra Herpes vírus equino tipo I e IV ${ }^{8}$ e anualmente contra encefalomielite ${ }^{9}$, rinopneumonite ${ }^{9}$, influenza ${ }^{9}$, tétano ${ }^{9}$, Streptococcus equi ${ }^{10}$, raiva ${ }^{11}$ e leptospirose ${ }^{12}$.

Os animais doadores de sangue foram vacinados em dois momentos com intervalo de 30 dias, sendo que em cada momento receberam vacinas contra encefalomielite ${ }^{9}$, rinopneumonite ${ }^{9}$, influenza ${ }^{9}$, tétano ${ }^{9}$, Rhodococcus equi ${ }^{6}$, E. coli $^{7}$ Salmonella $^{7}$, Klebsiella $^{7}$, Streptococcus equi ${ }^{10}$ e leptospirose ${ }^{12}$. Após 25 dias da segunda dose foi realizada a colheita de sangue para extração do plasma.

\section{Plasmoferese}

Após as colheitas de sangue dos doadores o plasma foi extraído por centrifugação ${ }^{13}$ a $740 \times$ g por 14 minutos a $4^{\circ} \mathrm{C}$ e congelado a $-20^{\circ} \mathrm{C}$. Este processamento foi realizado em um prazo máximo de seis horas após as colheitas do sangue total. Uma alíquota do plasma foi separada para determinação da concentração de IgG total. Todos os potros foram tratados por via intravenosa com um litro de plasma, independente do peso do animal, com 24 horas de vida. Para isto foi realizada tricotomia, antissepsia e acesso na veia jugular, com cateter intravenoso $16 \mathrm{G}$ acoplado a equipo de transfusão.

\section{Colheita das amostras}

As amostras de sangue das éguas e seus respectivos potros foram colhidas por venopunção da jugular utilizando coletor para coleta múltipla com agulha $-21 \mathrm{G}$ e acondicionadas em frascos sem anticoagulante. Após a retração do coágulo, as amostras foram centrifugadas a $1.800 \mathrm{xg}$ durante 10 minutos para obtenção do soro.

Amostras de sangue e colostro das éguas foram colhidas no momento do parto. A colheita de sangue dos potros ocorreu em cinco momentos: M1, imediatamente após o parto e previamente a primeira mamada do colostro; M2, com dez horas de vida; M3, com 24 horas de vida (logo após esta colheita foi realizada a transfusão do plasma); M4, com 48 horas de vida (24 horas após a transfusão

6 RHODOVAC $^{\circledR}$, Clinica Equina SRL, Cap. Sarmiento, Argentina.

7 AUTOVACUNA ${ }^{\circledR}$, Dr. L. Pompeo S., Argentina.

8 HERPES-HORSE ${ }^{\circledR}$, Lab. Vencofarma do Brasil, Londrina, PR.

9 LEXINGTON-8 ${ }^{\circledR}$, Lab. Vencofarma do Brasil, Londrina, PR. 10STREPTOVAC, Sorocaba, SP.

11 BGS-CELL ${ }^{\circledR}$, Hertape Calier Saúde Animal S/A, Juatuba, MG.

12 LEPTOEQUUS ${ }^{\circledR}$, Lab. Vencofarma do Brasil, Londrina, PR.

13 ROTANTA 460 RS HETTICH ZENTRIFUGEN, Hettich Lab. Technology, Tuttlingen, Alemanha. do plasma); M5, aos 30 dias de vida. Todas as amostras colhidas foram armazenadas em tubos plásticos e congeladas a $-20^{\circ} \mathrm{C}$ até o momento das análises laboratoriais.

Visando respeitar as condições estabelecidas pela propriedade onde foram realizadas as coletas das amostras, não foi possível utilizar um grupo de potros como controle, ou seja, sem receber plasma ou sem mamar colostro, uma vez que isto iria alterar o manejo profilático da propriedade aumentando o risco de problemas infecciosos e possivelmente acarretando em danos financeiros ao haras.

\section{Proteína total e frações proteicas séricas}

A concentração da PT sérica das éguas PSI, potros e os animais doadores foi mensurada utilizando dois diferentes métodos, refratômetro manual e analisador bioquímico semiautomático ${ }^{14}$ usando kit comercial ${ }^{15}$ para dosagem direta pelo método colorimétrico de biureto (Tietz 2008). 0 mesmo analisador bioquímico foi utilizado para determinar a concentração de albumina das amostras pelo método colorimétrico verde de bromocresol ${ }^{16}$ (Tietz 2008).

As frações proteicas, albumina, $\alpha 1$ (alfa1-globulinas), $\alpha 2$ (alfa2-globulinas), $\beta$ (beta-globulinas) e $\gamma$ (gama-globulinas) foram obtidas pela técnica de eletroforese em gel de agarose ${ }^{17}$ corado com amido negro $(0,1 \%)$ em ácido acético a $5 \%$, seguindo as técnicas descritas por Naoum (1999). A determinação das frações proteicas foi realizada em scanner SE-250 ${ }^{18}$, o valor de PT utilizado foi o obtido pela técnica do biureto em analisador bioquímico.

A concentração da globulina total sérica (GT) das amostras de soro e plasma foi determinada baseada nos valores das concentrações de albumina subtraída da proteína total. Para tal foram utilizados os valores de albumina e proteína total obtidos por reação colorimétrica em analisador bioquímico.

\section{Determinação da concentração de IgG total: padronização do teste de ELISA}

A concentração de IgG total das amostras de plasma, soro e colostro foi mensurada pelo método direto de sanduiche ELISA (S-ELISA) descrito por Erhard et al. (2001) com modificações. Para a realização do S-ELISA proposto foi necessária a purificação da IgG equina utilizada como padrão de referência e também a produção do anticorpo de coelho anti-IgG equina utilizado como captura no método de ELISA.

Purificação da IgG equina utilizada como padrão de referência. O processo de purificação, avaliação da pureza e quantificação do IgG equino seguiu a técnica descrita por Bollag et al. (1996). Para tal, uma amostra de soro foi obtida de um equino hígido, macho e adulto, sendo o volume de $5 \mathrm{~mL}$ utilizado para a purificação da IgG equina na coluna de afinidade (HiTrap Protein G HP) ${ }^{19}$, seguindo as recomendações do fabricante. Para a caracterização da imunoglobulina G obtida, as alíquotas coletadas durante a purificação foram submetidas ao SDS-PAGE (sodium dodecyl sulfate-polyacrylamide gel electrophoresis) 12,5\% corado com azul de coomassie. Após a realização do SDS-PAGE foram separadas as amostras onde foi observado apenas as bandas das cadeias leves e pesadas da molécula

14SB 190, CELM Cia, São Caetano do Sul, SP.

15PROTEINAS TOTAIS Katal ${ }^{\circledR}$, Katal Biotecnológica Ind. Com. Ltda, Belo horizonte, MG.

16ALBUMINA Katal ${ }^{\circledR}$, Katal Biotecnológica Ind. Com. Ltda, Belo horizonte, MG.

17 Celmgel $^{\circledR}$, CELM, Cia. Equipadora de Laboratórios Modernos, Barueri, SP.

18SE-250, CELM Cia, São Caetano do Sul, SP.

19GE Healthcare Bio-Sciences AB, Björkgatan 30751 84, Uppsala, Sweden. 
de IgG e realizada a quantificação proteica pelo método de BCA (ácido bicinconínico) (Smith et al. 1985).

Anticorpo de coelho anti-IgG equina. Seguindo a técnica descrita por Bollag et al. (1996), um coelho foi imunizado com 1mg de IgG equina purificada em $1 \mathrm{~mL}$ do adjuvante completo de Freund ${ }^{20}$ e inoculado por via intramuscular. Foram realizadas mais quatro aplicações semanais com a mesma concentração proteica e com adjuvante incompleto de Freund, alternando as vias de administração entre subcutânea e intramuscular. Após dez dias da última aplicação foi realizada a colheita de sangue para obtenção de soro e verificada a reatividade, por imunodifusão dupla em gel de ágar, contra a IgG equina purificada. Em seguida foi realizada a eutanásia e sangria total do coelho para obtenção do antissoro. Uma alíquota do antissoro foi submetida à purificação da IgG de coelho anti-IgG equina utilizando coluna de afinidade (HiTrap Protein A HP) ${ }^{21}$, conforme descrição e recomendações do fabricante.

Método de S-ELISA para determinação da IgG total. Em cada etapa a seguir, com exceção do bloqueio, foi utilizado um volume de $100 \mu \mathrm{L}$ de solução em cada poço da microplaca de poliestireno ${ }^{22}$. Também entre cada etapa de reação, exceto após a adição do substrato/cromógeno, a microplaca foi lavada cinco vezes com $300 \mu \mathrm{L} /$ poço de PBST $\left(0,01 \mathrm{M} \mathrm{PO4}^{-2} ; 0,14 \mathrm{M} \mathrm{NaCl} ; 0,05 \%\right.$ Tween 20; pH 7,4). 0 anticorpo de coelho anti-IgG equina foi utilizado como anticorpo de captura, sendo adsorvido na concentração de $0,5 \mu \mathrm{g} / \mathrm{mL}$ diluído em Tampão Carbonato Bicarbonato 0,05M pH 9,6 (TCB). Em seguida, a microplaca foi incubada a $37^{\circ} \mathrm{C}$ em câmara úmida durante 60 minutos.

Após o período de incubação, realizou-se a etapa de bloqueio com a adição de $300 \mu \mathrm{l} /$ poço do TCB acrescido de $10 \%$ leite em pó desnatado (LPD). Em seguida, foi realizada a incubação em câmara úmida por 45 minutos a $37^{\circ} \mathrm{C}$.

As amostras teste e padrão de referência foram diluídas com a solução diluente constituída de PBST acrescido de 10\% de LPD. As amostras de soro de potros do M1 foram diluídas 1:2.000 pelo fato de sua concentração de IgG ser menor, enquanto que as amostras de soro e plasma foram diluídas 1:40.000 e de colostro 1:80.000. Para cada microplaca foi construída uma curva padrão utilizando a IgG equina purificada que foi diluída seriadamente na razão 2 de $1 \mu \mathrm{g} / \mathrm{mL}$ a $0,015 \mu \mathrm{g} / \mathrm{mL}$. Posteriormente, foi efetuada incubação da microplaca em câmara úmida a $37^{\circ} \mathrm{C}$ por 60 minutos.

Após a fase de incubação foi adicionado o conjugado imunoenzimático IgG de coelho anti-IgG de equino conjugado com peroxidase ${ }^{23}$, o qual foi preparado na diluição de 1:4.000 com solução diluente de PBST. Essa fase foi incubada durante 60 minutos a $37^{\circ} \mathrm{C}$ em câmara úmida. Depois, foi adicionado em cada poço da microplaca a solução de substrato/cromógeno $\left(2,5 \mu \mathrm{l}\right.$ de $\mathrm{H}_{2} \mathrm{O}_{2}$ a $30 \%+100 \mu \mathrm{l}$ de Tetrametilbenzidina-TMB a $10 \mathrm{mg} / \mathrm{mL}$ em Dimetilsulfóxido-DMSO) em 10mL do Tampão Citrato Acetato 0,1M pH 6,0. A mesma foi mantida sob agitação constante durante 15 minutos em temperatura ambiente e protegida da luz. A reação colorimétrica foi bloqueada com a solução de $\mathrm{HCl} 2 \mathrm{M}$ no volume de $50 \mu \mathrm{l} /$ poço. A leitura da DO foi realizada em leitora automática ${ }^{24}$ em um comprimento de onda de 450nm contra um branco, no qual foi adicionado apenas o

20Freund's adjuvant, complete and incomplete. SIGMA ${ }^{\circledR}$, Sigma-Aldrich Brasil Ltda, São Paulo, SP.

21 GE Healthcare Bio-Sciences AB, Björkgatan 30751 84, Uppsala, Sweden.

22 NuncTM Medisorp, Thermo Fisher Scientific Inc.

23 A6917 SIGMA ${ }^{\circledR}$, Sigma-Aldrich Brasil Ltda, São Paulo, SP.

24Multiskan EX, Labsystems, Thermo Fisher Scientific Inc. reagente para bloqueio, o substrato/cromógeno e o bloqueador da reação colorimétrica. Como controle negativo da reação foi utilizado, em cada microplaca, poços sem amostras e considerados como satisfatório quando estes apresentaram DO's semelhante ao branco.

As D0's obtidas, em cada curva padrão, e as respectivas concentrações foram correlacionadas utilizando regressão polinomial de grau 2 e a equação quadrática para determinação da concentração de IgG das amostras. Posteriormente os valores obtidos foram multiplicados pelo fator de diluição de cada amostra. Foram apenas utilizados os dados das reações onde a curva padrão apresentou coeficiente de determinação $\left(R^{2}\right)>0,95$ e coeficiente de variação $(C V)<10 \%$ nas duplicatas de cada ponto da curva. Todas as amostras foram testadas em triplicatas e consideradas as que tiveram $\mathrm{CV}<10 \%$ e as que apresentaram concentrações superiores à curva padrão foram re-diluídas e re-analisadas.

Teste de repetibilidade S-ELISA. A repetibilidade intra e inter-ensaio, do S-ELISA foi avaliada utilizando a IgG equina purificada (utilizada como padrão) e as amostras de soro e colostro testadas. Para tal, foi avaliado o coeficiente de variação (CV) das DO's das amostras teste e padrão de referência, em duplicatas, dentro de uma mesma microplaca (intra-teste) e o CV das DO's das mesmas amostras em diferentes microplacas (inter-teste) (OIE 2014).

Foram realizadas cinco diluições seriadas de razão 2 da IgG equina padrão (de $1 \mu \mathrm{g} / \mathrm{mL}$ até $0,015 \mu \mathrm{g} / \mathrm{mL}$ ) e distribuídas, em duplicatas, em cinco pontos diferentes de uma mesma microplaca. A mesma diluição seriada foi avaliada em cinco microplacas diferentes, sendo que cada teste foi realizado em diferentes dias. Também foram escolhidas, aleatoriamente, dez amostras teste (cinco de soro e cinco de colostro) para serem testadas, em duplicata, em quatro pontos distintos de uma mesma microplaca, com o procedimento realizado três vezes em diferentes dias.

Para verificar a exatidão do teste, incluiu-se uma amostra com concentração conhecida como controle positivo. Todas as diluições, tanto da IgG padrão quanto das amostras teste foram realizadas de forma independente para cada ponto da microplaca.

\section{Análise do colostro}

O colostro das éguas PSI foi avaliado em um colostrômetro de refração BRIX ${ }^{25}$ (Cash 1999), imediatamente após o parto (antes dos potros mamarem).

No laboratório foi utilizado um colostrômetro de densidade específica ${ }^{26}$ (Leblanc et al. 1986). Posteriormente, foi realizada a centrifugação das amostras a $8000 \mathrm{xg}$, durante 15 minutos, a $4^{\circ} \mathrm{C}$ para separação da fração lipídica e proteica da fase aquosa que foi armazenada para quantificação de IgG total pelo método de ELISA padronizado.

\section{Análise estatística}

Todas as variáveis quantitativas foram testadas quanto à normalidade e homocedasticidade dos dados. Um modelo linear misto (PROC MIXED) ${ }^{27}$ foi utilizado para comparar a diferença entre as médias de PT dos potros, por diferentes testes, entre os cinco momentos e a concentração de IgG do grupo de potros obtidos nos cinco momentos. Demais variáveis quantitativas nos cinco momentos do grupo de

25 ARS Equine Colostrum Refractometer, Animal Reproduction Systems Inc., Califórnia, USA.

26 JorVet Equine Colostrometer, Jorgensen Laboratories Inc., Colorado, USA.

$27 \mathrm{SAS}^{\circledR}$, University Edition, SAS Institute Inc., North Carolina 27513, USA. 
Quadro 1. Média \pm desvio padrão da proteína total (determinados por diferentes métodos), albumina e globulinas totais dos potros $(n=20)$, nos cinco momentos, e éguas $(n=20)$ no momento do parto

\begin{tabular}{|c|c|c|c|c|c|c|c|}
\hline \multirow{2}{*}{ Proteínas (mg/dL) } & & \multicolumn{5}{|c|}{ Momentos } & \multirow{2}{*}{ Éguas } \\
\hline & & M1 & M2 & M3 & M4 & M5 & \\
\hline \multirow[t]{2}{*}{ PT (refratometria) } & $\overline{\mathrm{X}}$ & $4.350^{\mathrm{a}}{ }_{\mathrm{B}}$ & $6.080^{\mathrm{bc}}{ }_{\mathrm{B}}$ & $5.890^{\mathrm{b}}{ }_{\mathrm{B}}$ & $6.370^{\mathrm{c}}{ }_{\mathrm{B}}$ & $5.970^{b}$ & $7.140_{A}$ \\
\hline & \pm & 252 & 839 & 771 & 585 & 343 & 535 \\
\hline \multirow[t]{2}{*}{ PT (bioquímica) } & $\overline{\mathrm{X}}$ & $4.095^{a}{ }_{B}$ & $6.340^{\mathrm{b}}{ }_{\mathrm{B}}$ & $6.095^{\mathrm{b}}$ & $6.799^{c}{ }_{A}$ & $5.959^{a}{ }_{B}$ & 7.326 \\
\hline & \pm & 283 & 961 & 823 & 712 & 470 & 588 \\
\hline Albumina (bioquímica) & $\overline{\mathrm{X}}$ & $2.950^{\mathrm{a}}{ }_{\mathrm{B}}$ & $2.767^{\mathrm{b}}{ }_{\mathrm{B}}$ & $2.712^{\mathrm{b}}{ }_{\mathrm{B}}$ & $2.735^{\mathrm{b}}{ }_{\mathrm{B}}$ & $2.867^{\mathrm{ab}}{ }_{\mathrm{B}}$ & $3.555_{A}$ \\
\hline \multirow[t]{2}{*}{ Globulina total } & $\overline{\mathrm{X}}$ & $1.145^{\mathrm{a}}{ }_{\mathrm{B}}$ & $3.574_{\mathrm{A}}^{\mathrm{b}}$ & $3.383^{\text {bd }}$ & $4.064_{\mathrm{A}}^{\mathrm{c}}$ & $3.092^{\mathrm{d}}$ & 3.772 \\
\hline & \pm & 198 & 883 & 775 & 759 & 427 & 566 \\
\hline
\end{tabular}

M1 = logo após o parto, previamente mamar colostro, M2 = dez horas de vida, M3 = 24 horas de vida, previamente transfusão plasma hiperimune, M4 = 48 horas de vida, 24 horas após a transfusão do plasma, M5 = 30 dias de vida. Letras sobrescritas minúsculas iguais indicam médias semelhantes $(\mathrm{P}<0,05)$ entre os cinco momentos do grupo de potros e subscritas maiúsculas iguais indicam médias semelhantes $(\mathrm{P}<0,05)$ entre grupo de éguas com cada um dos momentos do grupo de potros.

potros foram submetidas à ANOVA de medidas repetidas e Tukey como teste a posteriori. Para comparação dos valores médios das variáveis quantitativas entre potros e éguas foi utilizado ANOVA-One Way e teste de múltiplas comparações de Tukey.

Para variável não paramétrica a comparação de medianas dependentes e independentes foram utilizados os testes de Friedman e Kruskal Wallis, respectivamente, seguidos do teste de múltiplas comparações de Dunn. Foi utilizado coeficiente de correlação de Pearson para as seguintes correlações: entre concentrações obtidas por diferentes métodos para PT do grupo de potros nos cinco momentos; entre concentrações de PT (ambos os métodos), gamaglobulina, globulina total e concentração de IgG total; entre concentração de IgG sérico e colostral das éguas; entre densidade (dois métodos) e concentração de IgG colostral; entre concentração de IgG colostral e IgG sérico dos potros. As análises estatísticas foram realizadas utilizando softwares computacionais ${ }^{28}$ e consideradas significativas quando $\mathrm{P}<0,05$.

\section{RESULTADOS E DISCUSSÃO}

A média de idade e tempo de gestação das éguas progenitoras foi de $13 \pm 5$ anos e $330 \pm 11$ dias, respectivamente. Dos 20 potros incluídos neste estudo 12 eram machos (60\%) e 8 fêmeas (40\%), o peso e altura média ao nascer foram de $51,24 \pm 7,31 \mathrm{~kg}$ e $99,75 \pm 5,06 \mathrm{~cm}$, respectivamente. 0 tempo médio para o potro se levantar foi de $41 \pm 20$ minutos de vida, isso ocorreu de forma espontânea e sem interferência humana, após foi realizado auxílio para a primeira mamada que ocorreu em um tempo médio de 74,1 $\pm 26,4$ minutos, sendo que todos os animais mamaram dentro dos primeiros 120 minutos após o nascimento.

É considerado como ideal um tempo de gestação de pelo menos 320 dias (Paradis 2006) e dois dos potros inclusos nesta pesquisa nasceram com menos de 320 dias de gestação, todavia, nenhum apresentou sinal indicativo de mau ajustamento neonatal ou apresentou FTIP. Estas informações estão de acordo com os já observados por outros autores em indivíduos da

28 GraphPad Prism ${ }^{\circledR}$ 5.01, GraphPad Software Inc., CA 92037, USA. mesma raça e com padrão de manejo semelhante aos animais deste estudo (Kurtz Filho et al. 1997).

\section{Proteína total, albumina e globulinas totais}

As medidas de tendência central e dispersão da PT obtidos por refratometria, PT e albumina obtidos pelo analisador bioquímico e GT estão dispostas no Quadro 1. Houve forte correlação $(\mathrm{r}=0,92 \mathrm{P}<0,001)$ entre os resultados obtidos nas duas técnicas de avaliação da PT sérica dos potros em todas as amostras dos cinco momentos (Fig.1A).

Os refratômetros manuais são amplamente utilizados para determinação de PT em amostras de fluidos corpóreos pela facilidade e rapidez no resultado, entretanto, devido à dependência da transmissão de luz é necessário que as amostras estejam limpas de coágulos, lipemia ou hemólise (Kaneko et al. 2008). Na comparação dos valores de PT de todas as amostras obtidos por refratometria e analisador bioquímico, não foi observada diferença estatística entre as técnicas de quantificação utilizadas. Os valores médios observados de PT após a primeira mamada estavam dentro do intervalo de referência (5.200-7.900mg/dL) para a espécie equina (Bauer et al. 1985, Kaneko et al. 2008). A albumina dos potros ao nascimento correspondeu a mais de $50 \%$ da PT e dentro dos valores considerados como normais para a espécie (Bauer et al. 1985, Kaneko et al. 2008).

Os níveis séricos da PT das éguas no momento do parto estavam de acordo com os valores de referência (Kaneko et al. 2008, Riond et al. 2009). Já albumina sérica das éguas se encontrava acima dos níveis descritos por Di Filippo et al. (2010) e Riond et al. (2009), o que é interessante, uma vez que os níveis séricos de albumina tendem a diminuir na fase final da gestação (Kaneko et al. 2008).

A GT sérica dos potros, nos cinco momentos, teve forte associação positiva com PT obtida por bioquímico e refratômetro ( $r=0,97$ e $r=0,89$ com $P<0,001$, respectivamente). Da mesma forma que na PT, foram observados dois picos de concentração de GT do grupo de potros, um no M2 com valores entre $2.135-5.050 \mathrm{mg} / \mathrm{dL}$ e outro no M4 entre $2.875-5.125 \mathrm{mg} / \mathrm{dL}$. 

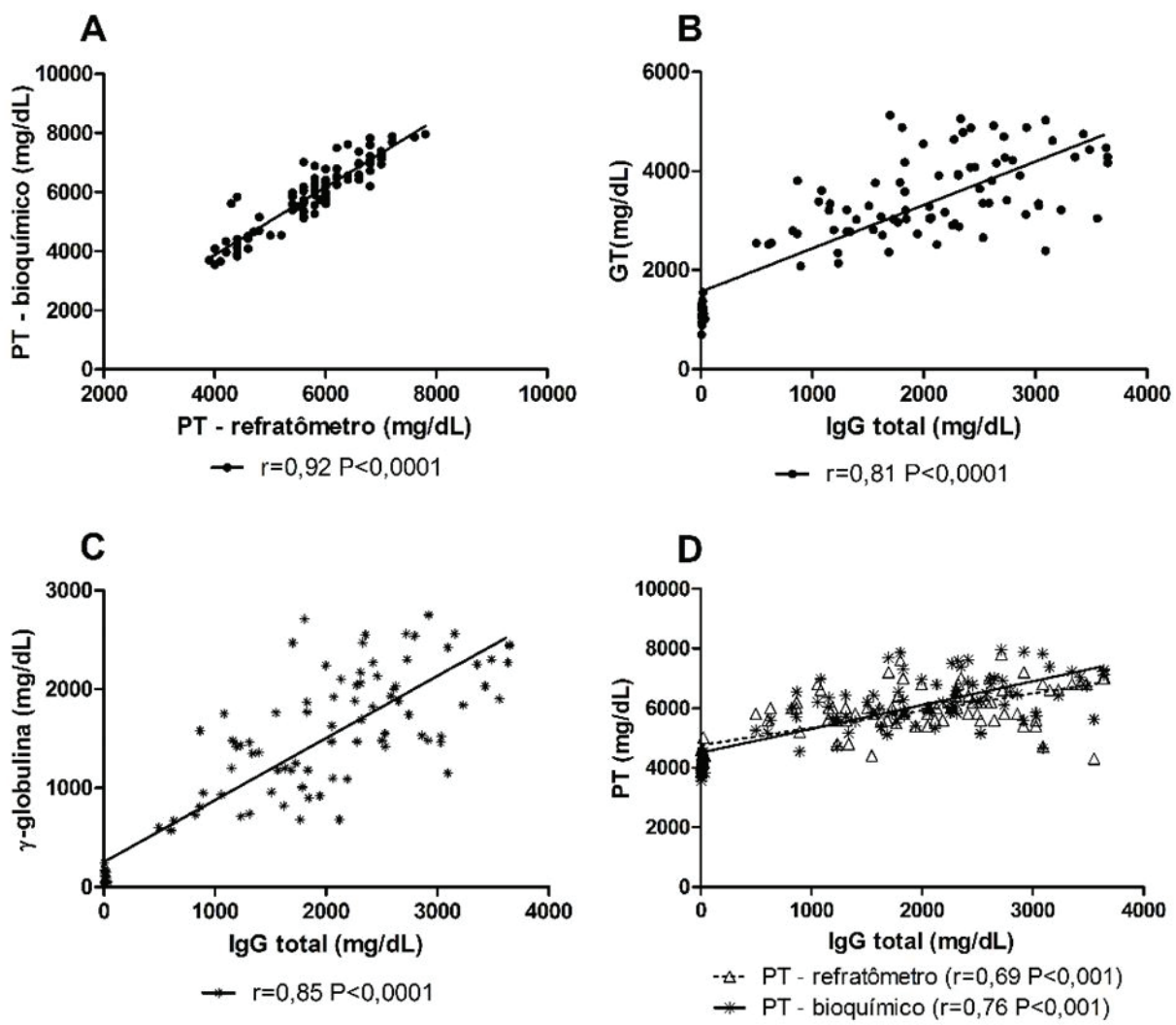

Fig.1. Representação gráfica das correlações positivas $(\mathrm{P}<0,001)$ entre variáveis analisadas de amostras de soro do grupo de potros ( $\mathrm{n}=20)$ nos cinco momentos (n=100). (A) PT obtida por refratômetro manual e analisador bioquímico r=0,92. (B) IgG obtida por S-ELISA e GT obtida por cálculo matemático $r=0,81$. (C) IgG sérica e fração $\gamma$-globulina obtida por eletroforese $r=0,85$. (D) IgG sérica e PT obtida tanto por refratômetro quanto pelo analisador bioquímico $r=0,69$ e $r=0,76$, respectivamente.

\section{Proteinograma (eletroforese em gel de agarose)}

Os potros apresentaram aumento na fração $\gamma$-globulina antes e após mamar o colostro (Fig.2). As medidas de tendência central e dispersão das concentrações séricas de PT e frações proteicas do grupo de potros (nos cinco momentos) e suas progenitoras (imediatamente após o parto) estão descritos no Quadro 2.

As frações $\alpha$ e $\beta$-globulinas são compostas por proteínas de fase aguda, e se elevam rapidamente em situações inflamatórias ou infecciosas (Kaneko et al. 2008, Favero et al. 2011). Equinos com problemas inflamatórios e infecciosos, especificamente enterites, diarreias agudas e inflamações articulares possuem níveis séricos elevados das subfrações $\alpha 1$ e $\beta$-globulinas quando comparados com animais hígidos (Carapeto et al. 2006). No presente estudo foi observado que as frações $\alpha$-globulinas permaneceram em níveis constantes de M1 a M3 (nascimento até 24 horas de vida) e estavam elevadas em M5 quando comparadas a M4, sendo que a fração $\alpha 1$ aumentou de forma significativa de M3 a M4 e de M4 a M5.

A fração $\beta$-globulina aumentou de forma significativa de M1 a M2 $(\mathrm{P}<0,05)$, manteve em níveis semelhantes de M2 a M3, aumentou significativamente $(\mathrm{P}<0,0001)$ de M3 a M4 e também no M5 quando comparado ao M3 $(\mathrm{P}<0,001)$. As frações alfa e beta globulinas detectadas na eletroforese compreendem uma série de proteínas de fase aguda tais como, proteína $\mathrm{C}$ reativa, hemopexina, transferrina, fibrinogênio e amilóide A, que aumentam rapidamente frente processos inflamatórios diversos (Murata et al. 2004, Kaneko et al. 2008), podendo algumas serem secretadas no colostro e leite de éguas (McDonald et al. 2001, Duggan et al. 2008). 0 perfil eletroforético de proteínas de fase aguda é utilizado para diagnóstico de sepse em potros, sabe-se que em potros septicêmicos ocorre um aumento significativo de amilóide A em processos agudos (Paltrinieri et al. 2008, Jacobsen \& Andersen 2010). Embora seja possível a ocorrência de reação alergênica devido a transfusão do plasma (Hurcombe et al. 2007, Wilson et al. 2009), uma vez que potros são mais susceptíveis a reações alergênicas transfusional e a taxa incidência de reação à transfusão de plasma em neonatos chega a 9,7\% (Hardefeldt et al. 2010). Todavia, não foram observados sinais clínicos de reação transfusional em nenhum dos potros utilizados nesta pesquisa, além disto, as frações $\alpha$ e $\beta$-globulinas estavam significativamente aumentadas em M5, ou seja, 28 dias após a transfusão, e uma reação transfusional não debelaria um aumento de proteínas de fase aguda tardia.

A fração $\gamma$-globulinas é composta pelas imunoglobulinas IgA, IgM, IgE e IgG (Kaneko et al. 2008), sendo esta última a imunoglobulina sérica mais abundante (Tizard 2004). Estão em quantidades muito pequenas nos potros ao nascer, aumentando nas primeiras horas de vida após ingerir colostro até atingir o pico de absorção entre 18 e 24 horas (Jeffcott 1974b). No presente estudo a concentração média 


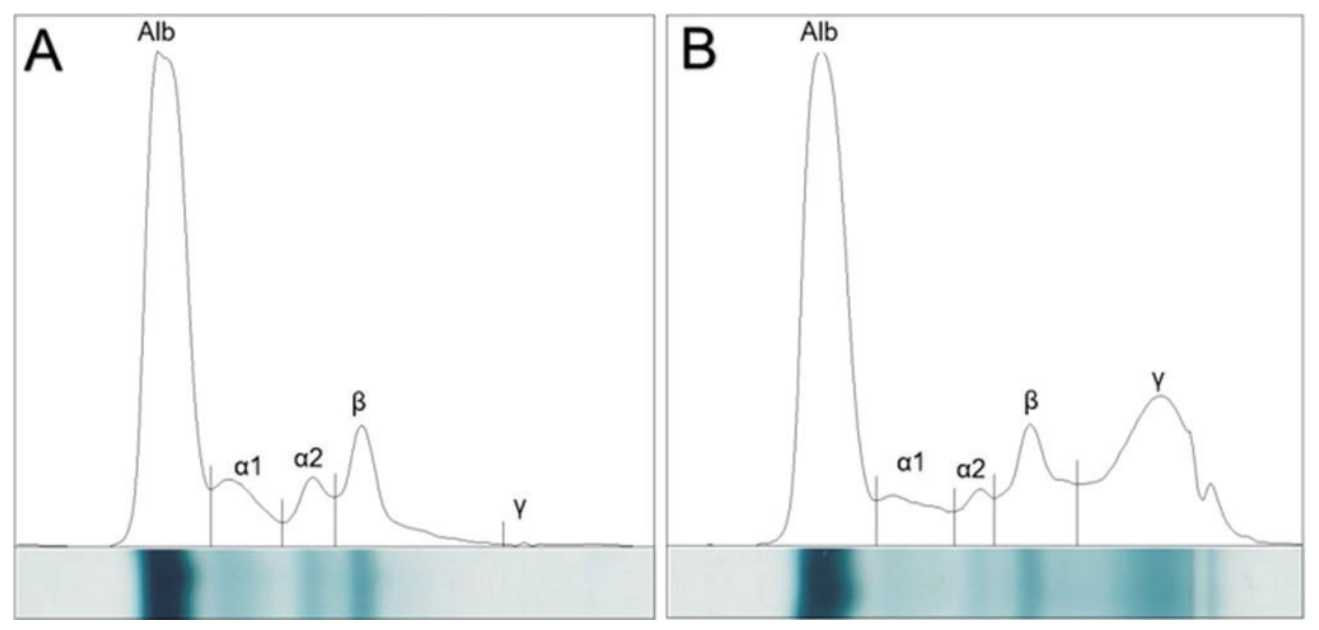

Fig.2. (A) Representação gráfica da leitura das frações proteicas séricas de um potro clinicamente saudável no M1 (logo após o parto, previamente mamar colostro) e (B) M2 (dez horas de vida). Os picos representam, da esquerda para a direita, as bandas albumina, $\alpha 1, \alpha 2, \beta$ e $\gamma$-globulinas no gel de agarose. Notar a fração gamaglobulina virtualmente inexistente em M1 (A) onde o potro ainda não havia mamado o colostro.

Quadro 2. Medidas de tendência central e dispersão da proteína total (PT) obtida no analisador bioquímico, das frações proteicas - Alb. (albumina), $\alpha 1$ (alfa1-globulina), $\alpha 2$ (alfa2-globulina), $\beta$ (beta-globulina) e $\gamma$ (gamaglobulina) - pela eletroforese e IgG total por $S$-ELISA dos potros $(n=20)$ nos cinco momentos e éguas progenitoras $(n=20)$ no momento do parto

\begin{tabular}{|c|c|c|c|c|c|c|c|}
\hline \multirow{2}{*}{\multicolumn{2}{|c|}{ Proteínas (mg/dL) }} & \multicolumn{5}{|c|}{ Potros $(n=20)$} & \multirow{2}{*}{ Éguas $(n=20)$} \\
\hline & & \multirow{2}{*}{$\frac{\mathrm{M} 1}{4.095^{\mathrm{a}}}$} & \multirow{2}{*}{$\frac{\mathrm{M} 2}{6.340^{\mathrm{b}}}$} & \multirow{2}{*}{$\frac{\text { M3 }}{6.095^{\mathrm{b}}}$} & \multirow{2}{*}{$\frac{\mathrm{M} 4}{6.799^{\mathrm{c}}}$} & \multirow{2}{*}{$\frac{\mathrm{M} 5}{5.959^{\mathrm{a}}{ }_{\mathrm{B}}}$} & \\
\hline PT & $\bar{X}$ & & & & & & $7.326_{\mathrm{A}}$ \\
\hline & \pm & 283 & 961 & 823 & 712 & 470 & 588 \\
\hline \multirow[t]{2}{*}{ Alb } & $\overline{\mathrm{X}}$ & $2.617^{\mathrm{a}}{ }_{\mathrm{B}}$ & $2.925^{\mathrm{bc}}{ }_{B}$ & $2.799^{\mathrm{b}}{ }_{\mathrm{B}}$ & $3006^{c}{ }_{B}$ & $2.589^{a}{ }_{B}$ & $3.659_{\mathrm{A}}$ \\
\hline & \pm & 358 & 332 & 377 & 267 & 241 & 335 \\
\hline \multirow[t]{2}{*}{$\alpha 1$} & $\overline{\mathrm{X}}$ & $377^{\mathrm{a}}{ }_{\mathrm{A}}$ & $400^{\mathrm{ab}}{ }_{\mathrm{A}}$ & $391^{a}{ }_{A}$ & $454^{\mathrm{b}}{ }_{\mathrm{A}}$ & $586^{c}{ }_{B}$ & $411_{\mathrm{A}}$ \\
\hline & \pm & 82 & 104 & 78 & 116 & 118 & 98 \\
\hline \multirow[t]{2}{*}{$\alpha 2$} & $\bar{X}$ & $368^{\mathrm{a}}{ }_{\mathrm{A}}$ & $371_{\mathrm{A}}^{\mathrm{a}}$ & $338^{\mathrm{a}}{ }_{\mathrm{A}}$ & $367^{\mathrm{a}}{ }_{\mathrm{A}}$ & $456^{\mathrm{b}}{ }_{\mathrm{A}}$ & $421_{\mathrm{A}}$ \\
\hline & \pm & 79 & 98 & 132 & 89 & 64 & 70 \\
\hline \multirow[t]{2}{*}{$\beta^{*}$} & Mediana & $660^{\mathrm{a}}{ }_{\mathrm{B}}$ & $780^{\mathrm{b}}$ & $775^{\mathrm{ab}}{ }_{\mathrm{B}}$ & $1.055^{\mathrm{cd}}{ }_{\mathrm{A}}$ & $1.325^{\mathrm{d}}$ & $1.215_{\mathrm{A}}$ \\
\hline & Min/Max & $250 / 750$ & $550 / 1.390$ & $490 / 1.000$ & $720 / 1.290$ & $920 / 1.720$ & $850 / 1.900$ \\
\hline \multirow[t]{2}{*}{$\gamma$} & $\overline{\mathrm{X}}$ & $84^{\mathrm{a}}{ }_{\mathrm{B}}$ & $1.816^{\mathrm{b}}{ }_{\mathrm{A}}$ & $1.805^{\mathrm{b}}$ & $1.911_{\mathrm{A}}^{\mathrm{b}}$ & $976.5^{c}$ & $1.580_{\mathrm{A}}$ \\
\hline & \pm & 59 & 572 & 463 & 451 & 337 & 330 \\
\hline \multirow[t]{2}{*}{ IgG } & $\overline{\mathrm{X}}$ & $15^{\mathrm{a}}{ }_{\mathrm{B}}$ & $2.408^{\mathrm{b}}{ }_{\mathrm{B}}$ & $2.282^{\mathrm{bd}}{ }_{\mathrm{A}}$ & $2.364^{\mathrm{b}}{ }_{\mathrm{B}}$ & $1.414_{\mathrm{A}}^{\mathrm{c}}$ & $1.746_{\mathrm{A}}$ \\
\hline & \pm & 8 & 628 & 783 & 784 & 586 & 505 \\
\hline
\end{tabular}

* Variável considerada não paramétrica, valores de tendência central representados por mediana e de dispersão representados por mínimo e máximo. M1 = logo após o parto, previamente mamar colostro, M2 = dez horas de vida, M3 = 24 horas de vida, previamente transfusão plasma hiperimune, M4 = 48 horas de vida (24 horas após administração do plasma hiperimune), M5 = 30 dias de vida. Letras sobrescritas minúsculas iguais indicam médias semelhantes $(\mathrm{P}<0,05)$ entre os cinco momentos do grupo de potros e subscritas maiúsculas iguais indicam médias semelhantes $(\mathrm{P}<0,05)$ entre grupo de éguas com cada um dos momentos dos potros.

da fração $\gamma$-globulina para o grupo foi de $83,5 \mathrm{mg} / \mathrm{dL}$ $(55,86-111,1 \mathrm{mg} / \mathrm{dL}$ com IC $95 \%)$ ao nascimento, aumentando significativamente $(\mathrm{P}<0,0001)$ para $1.816 \mathrm{mg} / \mathrm{dL}(1.548-$ $2.084 \mathrm{mg} / \mathrm{dL}$ com IC 95\%) com 10 horas após nascimento e não diferindo dos valores observados com 24 e 48 horas de vida, sugerindo que o pico de absorção de imunoglobulinas, contidas na fração gama, pode ocorrer até as dez horas de vida, mais cedo do que os resultados observados em trabalhos anteriores (Jeffcott 1974b, Tscheschlok et al. 2017).
Aos 30 dias a concentração sérica média de $\gamma$-globulina diminuiu significativamente $(\mathrm{P}<0,05)$ para $976,5 \mathrm{mg} / \mathrm{dL}$ (818,8-1.134mg/dL com IC 95\%) devido ao tempo de meia vida dos principais subtipos de IgG variarem de 18 e 32 dias (Sheoran et al. 2000). Todavia, em M5 a média da concentração da fração $\gamma$-globulina dos potros ainda estava em níveis considerados como suficientes para promover proteção contra agentes infecciosos (Jeffcott 1974b, Kohn et al. 1989). 
A correlação positiva $(\mathrm{P}<0,0001)$ entre a concentração da fração $\gamma$-globulina e as concentrações de PT determinadas por refratometria $(r=0,83)$ e bioquímico $(r=0,91)$ dos potros sugere que a aferição da PT pode ser utilizada para estimar a concentração de $\gamma$-globulina e identificar possíveis casos de FTIP na propriedade, pois refratômetros manuais são de simples operação e baixo custo. Tais observações corroboram com resultados relatados por Korosue e colaboradores (2012), onde afirmam que a diferença da concentração da PT antes e após potros mamarem colostro pode ser utilizada como teste de triagem para FTIP.

\section{Determinação IgG total}

No teste de repetibilidade do S-ELISA foram observados que os coeficientes de variação (CV) intra e inter-ensaio das curvas padrão foram $\mathrm{CV}<9,5 \%$ e $\mathrm{CV}<11,6 \%$, respectivamente, com limites de detecção de $62 \mathrm{ng} / \mathrm{mL}$ a $1.000 \mathrm{ng} / \mathrm{mL}$. Já o CV intra e inter-ensaio das amostras avaliadas foram $<9,7 \%$ e $<15,7 \%$, respectivamente. A concentração média estimada para amostra controle $(800 \mathrm{mg} / \mathrm{dL})$ em seis corridas diferentes foi de $796 \pm 181 \mathrm{mg} / \mathrm{dL}$ o que corresponde a uma precisão de 96\%. Estes resultados sugerem uma boa acurácia, tendo em vista a repetibilidade e precisão do teste (Greiner \& Gardner 2000, OIE 2014).

Além da acurácia, outro aspecto interessante do sistema de S-ELISA, aqui demonstrado, foi a facilidade e rapidez dos resultados obtidos, pois da primeira fase (sensibilização da microplaca) até a leitura das placas foram de aproximadamente cinco horas, sendo mais rápido que o teste de ELISA proposto por Erhard et al. (2001) e testes de IDRS, onde há a necessidade de 24 horas de difusão para se realizar as leituras (LeBlanc et al. 1986, Kohn et al. 1989, McClure et al. 2001, Raidal et al. 2005, Lang et al. 2007).

Estão dispostos no Quadro 2 as médias e desvios padrão das concentrações de IgG séricas de potros e éguas. A média e desvio padrão da concentração de IgG total das amostras de plasma utilizado nos potros em M3, foi de $2.026 \pm 148 \mathrm{mg} / \mathrm{dL}$.

Não houve diferença significativa quando comparados os níveis de IgG sérico dos potros às 10, 24 e 48 horas de vida. No M2 (10 horas) os potros apresentavam níveis séricos de IgG maiores $(\mathrm{P}<0,01)$ que o das éguas progenitoras no momento do parto e que do plasma utilizado. Tanto os níveis séricos de IgG quanto da fração $\gamma$-globulina dos potros já estavam em valores máximos encontrados com 10 horas de vida e não diferiram dos valores encontrados com 24 e 48 horas de vida, assim consideramos que potros que mamam uma quantidade adequada de colostro até duas horas de vida pode atingir o pico de absorção de imunoglobulinas colostrais até 10 horas de vida, corroborando com as observações de Hofsaess (2001), onde relatou que com nove horas pós nascimento seja o melhor momento para o diagnóstico de FTIP em potros.

Os potros aqui acompanhados atingiram o pico de concentração sérico de IgG colostral mais cedo do que o relatado pela literatura onde estabeleceu-se que o pico de absorção ocorre entre 12 e 18 horas pós nascimento (Jeffcott 1974b, LeBlanc et al. 1986, Lang et al. 2007, Korosue et al. 2012, Tscheschlok et al. 2017). Todavia, em nenhuma dessas publicações foi relatado algum tipo de auxílio para facilitar que os potros mamassem o mais cedo possível uma vez que os animais aqui acompanhados foram auxiliados no momento de procura à glândula mamária da mãe, e todos mamaram dentro dos primeiros 120 minutos após nascimento, demonstrando que o manejo de acompanhamento dos partos pode ser útil na prevenção de FTIP (LeBlanc et al. 1986, Korosue et al. 2012).

A concentração de IgG sérica do grupo de potros não diferiu significativamente de M3 para M4, ou seja, antes e após administração de plasma. A concentração média de IgG das bolsas de plasma utilizadas nos potros foi de $2.026 \pm 148 \mathrm{mg} / \mathrm{dL}$, cada potro recebeu em média uma dose de IgG de $403,8 \pm 63,1 \mathrm{mg} / \mathrm{Kg}$ de peso vivo o que foi insuficiente para aumentar significativamente a concentração média de IgG sérico do grupo 24 horas após transfusão. Talvez não houvesse aumento significativo na concentração de IgG total dos potros aqui avaliados devido a concentração sérica já estar elevada e com exceção de anticorpos específicos os valores séricos de imunoglobulinas não aumentem a partir de certas concentrações, ou o volume e/ou concentração de IgG no plasma transfundido não tenha sido suficiente, se fazendo necessário um volume maior de plasma fresco congelado. 0 mesmo foi observado por autores que utilizaram concentrado de IgG comercial em potros hígidos e sem FTIP por via oral (Hammer et al. 2000). Por outro lado, em um trabalho experimental utilizando potros com FTIP induzida os autores demostram o aumento das concentrações séricas de IgG de pelo uso de produto comercial de uso oral e/ou intravenoso, porém com concentrações $<500 \mathrm{mg} / \mathrm{dL}$ (Franz et al. 1998). Em outro trabalho, os autores avaliaram diferentes doses de diferentes produtos comerciais em potros com FTIP parcial e total, verificando aumento na concentração sérica de IgG três dias após o tratamento (Deluca et al. 2001). Além do aumento de anticorpos séricos já foi observado anteriormente que em potros saudáveis e sépticos tratados com plasma, houve aumento da atividade fagocítica do grupo de potros sépticos após tratamento (McTaggart et al. 2005). Recentemente foi demostrado a eficácia de plasma fresco congelado com concentração $>24 \mathrm{~g} / \mathrm{L}$ de IgG em aumentar de forma significativa a concentração sérica de IgG em potros com FTIP, para valores $>800 \mathrm{mg} / \mathrm{dL} 24$ e 72 horas pós transfusão, quando utilizado um volume médio de $1.340 \pm 578 \mathrm{~mL}$ por potro (Francesca et al. 2017).

Aos 30 dias de vida houve diminuição significativa da concentração de IgG em todos os potros, provavelmente decorrente do catabolismo dessas imunoglobulinas no processo de defesa do neonato (Jeffcott 1974a, Csapó-Kiss et al. 1995, Flaminio et al. 2000, Raidal et al. 2005). Ainda assim, a concentração de IgG foi quase o dobro do que é considerado como ideal para proteção de indivíduos da espécie contra infecções (Kohn et al. 1989, McClure et al. 2001), mas alguns potros possuíam valores marginais próximos ao mínimo recomendado.

A concentração de IgG sérica dos potros, aferida pelo S-ELISA, foi maior nas primeiras 24 horas após o nascimento e semelhante aos 30 dias de vida do que os resultados obtidos previamente utilizando a mesma técnica (Erhard et al. 2001, Sedlinská et al. 2006). Nas éguas, a concentração de IgG sérico foi similar e a colostral foi superior aos dados da literatura supracitada. Entretanto, os autores não relataram se as éguas progenitoras foram submetidas à algum tipo de protocolo vacinal na fase final de gestação. A vacinação das éguas no período pré-parto influencia a concentração de IgG séricas e/ou colostrais das éguas e, consequentemente, a concentração 
sérica dos potros (Cauchard et al. 2004, Martins et al. 2010). Corroborando com nossos resultados, tem sido demonstrado que potros hígidos nascidos de éguas vacinadas possuíam níveis de IgG séricos tão altos quanto os observados neste estudo (Flaminio et al. 1999).

Houve correlação positiva entre os valores de IgG e PT sérica dos potros com $r=0,69$ e $r=0,76$ para os valores obtidos por refratometria e analisador bioquímico, respectivamente (Fig.1D). Também foi observado correlação positiva do IgG total com GT dos potros (r=0,81) (Fig.1B) concordando com achados demonstrando alta associação GT e concentração de IgG, porém esta obtida por IDRS (Hurcombe et al. 2012, Tscheschlok et al. 2017).

A evidência de correlação positiva entre concentração da fração $\gamma$-globulina e concentração de IgG dos potros, quando as amostras nos cinco momentos foram avaliadas em conjunto $(\mathrm{r}=0,85 \mathrm{P}<0,001)$, corrobora com os valores relatados na literatura (Hurcombe et al. 2012, Fouché et al. 2014). Porém, em 62\% (62/100) das amostras, aqui analisadas, a fração $\gamma$-globulina foi menor que os valores encontrados para a concentração de IgG, resultado semelhante ao observado por Tscheschlok et al. (2017). Um fator deletério da técnica de eletroforese em gel de agarose é que devido a impurezas na agarose a eletroendosmose pode induzir migração errática de parte da fração $\gamma$-globulina em direção ao cátodo (Kaneko et al. 2008) e, desta maneira, influenciar na leitura e subquantificação desta fração.

Alguns autores sugerem o monitoramento da FTIP em potros utilizando valores de PT inferiores a $4.800 \mathrm{mg} / \mathrm{dL}$ (Metzger et al. 2006) e globulinas totais sérica $\leq 2.230 \mathrm{mg} / \mathrm{dL}$ (Hurcombe et al. 2012 ) ou $\gamma$-globulinas $\leq 800 \mathrm{mg} / \mathrm{dL}$ (Fouché et al. 2014). Apesar das médias observadas para PT, GT e $\gamma$-globulinas estarem em níveis acima dos considerados críticos para o diagnóstico de FTIP a partir das 10 horas até os 30 dias de vida, observou-se que no M2, um potro apresentou valores inferiores para PT, GT e $\gamma$-globulinas, um segundo potro apresentou valor de PT inferior e um terceiro estava com valor de GT abaixo do recomentado. Todavia, nenhum dos três animais apresentavam valores de IgG abaixo de $1.200 \mathrm{mg} / \mathrm{dL}$. A utilização dessas variáveis de forma isolada e rotineiramente para diagnóstico de FTIP podem levar a resultados insidiosos e ocasionar a perda de potros por doenças devido resultados falso-negativos ou gastos dispendiosos por resultados falso-positivos (Davis \& Giguère 2005), sendo aconselhável utiliza-las sempre em conjunto com dados clínicos e avaliação da concentração de IgG sérico (Metzger et al. 2006, Liepman et al. 2015).

Com a detecção precoce de FTIP é possível adotar medidas de suplementação de imunoglobulinas, tanto por colostro (banco de colostro) quanto por produtos de uso oral ou intravenoso (Franz et al. 1998, Deluca et al. 2001, Hammer et al. 2001, McTaggart et al. 2005), aproveitando melhor capacidade de absorção pelos potros.

\section{Densidade e concentração de IgG colostral}

A média e desvio padrão da densidade específica foi de $1.080 \pm 0.017$, o índice BRIX foi de $28,05 \pm 2,72 \%$ e a concentração de IgG colostral foi de $7.714 \pm 2.619 \mathrm{mg} / \mathrm{dL}$.

Não foi encontrada correlação entre a concentração de IgG sérica e colostral das éguas, corroborando com resultados observados por Kohn et al. (1989). Houve fraca correlação positiva $(r=0,44)$ entre a densidade específica e índice BRIX do colostro no momento do parto. Foi observada fraca, no entanto idêntica, correlação positiva $(r=0,47 p<0,05)$ entre concentração de IgG determinado por S-ELISA e a densidade avaliada pelos dois tipos de colostrômetro. Korosue et al. (2012) observaram correlação negativa entre índice BRIX e concentração de IgG de colostro de éguas. Essas diferenças de associação podem ser explicadas por fatores que influenciam na densidade colostral como temperatura ambiente (LeBlanc et al. 1986), e amostras com concentrações abaixo de $5.000 \mathrm{mg} / \mathrm{dL}$ de IgG (Waelchli et al. 1990). Outro fator que deve ser considerado é a idade das éguas aqui avaliadas que variou de 8 a 24 anos, além do tempo de gestação e número de partos que variaram de 316 a 355 dias e de 1 a 12 partos, respectivamente. Isto pode ter influenciado na correlação entre densidade especifica e concentração de IgG, uma vez que ambas variáveis mudam conforme idade, número de partos, tempo de gestação e raça (Waelchli et al. 1990, LeBlanc et al. 1992).

Já foi demonstrado que potros saudáveis absorvem até $50 \%$ da IgG colostral nas primeiras 12 horas de vida (Raidal et al. 2005). Todavia, aqui observamos fraca correlação $(r=0,46)$ entre a concentração de IgG colostral no momento do parto e a concentração de IgG sérica dos potros, com 10 horas de vida, corroborando com os achados de Erhard et al. (2001).

\section{CONCLUSÕES}

O método de S-ELISA padronizado permitiu determinar as concentrações de IgG em amostras de soro, plasma e colostro equino com uma boa repetibilidade.

Com a faixa de detecção do método de S-ELISA foi possível avaliar que um litro de plasma administrado em cada potro não foi suficiente para aumentar as concentrações séricas de IgG 24 horas após transfusão em potros sem falha de transferência de imunidade passiva.

Foi possível também verificar que dez horas após o nascimento, potros que mamam colostro em quantidade e com qualidade adequada, se encontram no pico de absorção de imunoglobulinas.

Agradecimentos.- À Fundação de Amparo à Pesquisa do Estado de São Paulo (FAPESP) pela concessão de uma bolsa de mestrado (Processo no2014/13328-7).

\section{REFERÊNCIAS}

Baldwin J.L., Cooper W.L., Vanderwall D.K. \& Erb H.N. 1991. Prevalence (treatment days) and severity of illness in hypogammaglobulinemic and normogammaglobulinemic foals. J. Am. Vet. Med. Assoc. 198(3):423-428 PMid:2010335.

Bauer J.E., Harvey J.W., Asquith R.L., Mcnulty P.K. \& Kivipelto J. 1985. Serum protein reference values in foals during the first year of life: comparison of chemical and electrophoretic methods. Vet. Clin. Pathol. 14(1):14-22. http://dx.doi.org/10.1111/j.1939-165X.1985.tb00841.x. PMid:15221688.

Bollag D.M., Rozycki M.D. \& Edelstein S.J. 1996. Protein Methods. 2nd ed. Wiley-Liss Inc., New York, p.313-325.

Carapeto M.V., Barrera R., Mañe M.C. \& Zaragoza C. 2006. Serum $\alpha$-globulin fraction in horses is related to changes in the acute phase proteins. J. Equine Vet. Sci. 26(3):120-127. http://dx.doi.org/10.1016/j.jevs.2006.01.007.

Cash R.S.G. 1999. Colostral quality determined by refractometry. Equine Vet. Educ. 11(1):36-38. http://dx.doi.org/10.1111/j.2042-3292.1999.tb00916.x.

Caston S.S., McClure S.R., Martens R.J., Chaffin M.K., Miles K.G., Griffith R.W. \& Cohen N.D. 2006. Effects of hyperimmune plasma on the severity of 
pneumonia caused by rhodococcus equi in experimentally infected foals. Vet. Ther. 7(4):361-375. PMid:17216591.

Cauchard J., Sevin C., Ballet J.J. \& Taouji S. 2004. Foal IgG and opsonizing anti-Rhodococcus equi antibodies after immunization of pregnant mares with a protective VapA candidate vaccine. Vet. Microbiol. 104(1/2):73-81. http://dx.doi.org/10.1016/j.vetmic.2004.09.006. PMid:15530741.

Clabough D.L., Levine J.F., Grant G.L. \& Conboy H.S. 1991. Factors associated with failure of passive transfer of colostral antibodies in standardbred foals. J. Vet. Intern. Med. 5(6):335-340. http://dx.doi.org/10.1111/j.1939-1676.1991. tb03147.x. PMid:1779427.

Costa M.C., Flaiban K.K.M.C., Coneglian M.M., Feitosa F.L.F., Balarin M.R.S. \& Lisbôa J.A.N. 2008. Transferência de imunidade passiva em bezerros das raças Nelore e Limousin e proteinograma sérico nos primeiros quatro meses de vida. Pesq. Vet. Bras. 28(9):410-416. http://dx.doi.org/10.1590/ S0100-736X2008000900003.

Csapó-Kiss Z., Stefler J., Martin T.G., Makray S. \& Csapó J. 1995. Composition of mares' colostrum and milk: protein content, amino acid composition and contents of macro and micro-elements. Int. Dairy J. 5(4):403-415. http://dx.doi.org/10.1016/0958-6946(94)00014-G.

Davis E.G. 2016. Immunoglobulin therapy, p.251-255. In: Felippe M.J.B. (Ed), Equine Clinical Immunology. John Wiley \& Sons Inc., Hoboken, New Jersey. http://dx.doi.org/10.1002/9781119086512.

Davis R. \& Giguère S. 2005. Evaluation of five commercially available assays and measurement of serum total protein concentration via refractometry for the diagnosis of failure of passive transfer of immunity in foals. J. Am. Vet. Med. Assoc. 227(10):1640-1645. http://dx.doi.org/10.2460/ javma.2005.227.1640. PMid:16313044.

Deluca J.L., McClure J.T., Lunn D.P. \& Miller J. 2001. Evaluation of IgG concentration in foals with failure of passive transfer after administration of intravenous serum or plasma. Proceedings of the 47th AAEP Annual Convention, San Diego, California, p.380-384. (Resumo)

DiFilippo P.A., Nogueira A.F.S., Anai L.A., Alves A.E., Santana A.E. \& Pereira G.T. 2010. Perfil eletroforético das proteínas séricas e do líquido peritoneal de equinos submetidos à obstrução experimental do duodeno, íleo e cólon maior. Ciênc. Anim. Bras. 11(4):938-946. http://dx.doi.org/10.5216/ cab.v11i4.9699.

Duggan V.E., Holyoak G.R., Macallister C.G., Cooper S.R. \& Confer A.W. 2008. Amyloid A in equine colostrum and early milk. Vet. Immunol. Immunopathol. 121(1/2):150-155. http://dx.doi.org/10.1016/j.vetimm.2007.06.030. PMid:17681383.

Erhard M.H., Luft C., Remler H.P. \& Stangassinger M. 2001. Assessment of colostral transfer and systemic availability of immunoglobulin G in newborn foals using a newly developed enzyme-linked immunosorbent assay (ELISA) system. J. Anim. Physiol. Anim. Nutr. 85(5/6):164-173. http:// dx.doi.org/10.1046/j.1439-0396.2001.00313.x. PMid:11686785.

Favero D.H.M.F., Dias D.P.M., Feringer-Junior W.H., Bernardi N.S. \& LacerdaNeto J.C. 2011. Serum protein profile in Arabian foals recently weaned or at more than thirty days after weaning. Pesq. Vet. Bras. 31(Suppl.1):89-93. http://dx.doi.org/10.1590/S0100-736X2011001300015.

Feitosa F.L.F., Camargo D.G., Yanaka R., Mendes L.C.N., Peiró J.R., Bovino F., Lisboa J.A.N., Perri S.H.V. \& Gasparelli E.R.F. 2010. Índices de falha de transferência de imunidade passiva (FTIP) em bezerros holandeses e nelores, às 24 e 48 horas de vida: valores de proteína total, de gamaglobulina, de imunoglobulina $\mathrm{G}$ e da atividade sérica de gamaglutamiltransferase, para o diagnóstico. Pesq. Vet. Bras. 30(8):696-704. http://dx.doi.org/10.1590/ S0100-736X2010000800015.

Flaminio M.J.B., Rush B.R., Davis E.G., Hennessy K., Shuman W. \& Wilkerson M.J. 2000. Characterization of peripheral blood and pulmonary leukocyte function in healthy foals. Vet. Immunol. Immunopathol. 73(3/4):267-285. http://dx.doi.org/10.1016/S0165-2427(00)00149-5. PMid:10713340.

Flaminio M.J.B.F., Rush B.R. \& Shuman W. 1999. Peripheral blood lymphocyte subpopulations and immunoglobulin concentrations in healthy foals and foals with Rhodococcus equi pneumonia. J. Vet. Intern. Med. 13(3):206-212. http://dx.doi.org/10.1111/j.1939-1676.1999.tb02180.x. PMid:10357110.
Fouché N., Graubner C. \& Howard J. 2014. Correlation between serum total globulins and gamma globulins and their use to diagnose failure of passive transfer in foals. Vet. J. 202(2):384-386. http://dx.doi.org/10.1016/j. tvjl.2014.08.013. PMid:25201248.

Francesca F., Jole M., Aliai L., Chiara C. \& Carolina C. 2017. Efficacy and safety of a commercial fresh-frozen hyperimmune plasma in foals with failure of passive transfer of immunity. J. Equine Vet. Sci. 48(2):174-181. http:// dx.doi.org/10.1016/j.jevs.2016.08.019.

Franz L.C., Landon J.C., Lopes L.A., Marinho L.A., Sarma C., Bruemmer J. \& Squires E.L. 1998. Oral and intravenous immunoglobulin therapy in neonatal foals. J. Equine Vet. Sci. 18(11):742-748. http://dx.doi.org/10.1016/ S0737-0806(98)80505-4.

Gasparelli E.R.F., Camargo D.G., Yanaka R., Perri S.H.V., Nogueira G.P., Lisboa J.A.N. \& Feitosa F.L.F. 2009. Teores séricos de proteína total, imunoglobulina ge Cortisol em bezerros nelore, ao nascimento e às 24 horas De vida: influência do tipo e da duração dos partos. ARS Veterinária 18:120-124.

Giguère S., Gaskin J.M., Miller C. \& Bowman J.L. 2002. Evaluation of a commercially available hyperimmune plasma product for prevention of naturally acquired pneumonia caused by Rhodococcus equi in foals. J. Am. Vet. Med. Assoc. 220(1):59-63. http://dx.doi.org/10.2460/javma.2002.220.59. PMid:12680449.

Greiner M. \& Gardner I.A. 2000. Epidemiologic issues in the validation of veterinary diagnostic tests. Prev. Vet. Med. 45(1/2):3-22. http://dx.doi. org/10.1016/S0167-5877(00)00114-8. PMid:10802331.

Haas S.D., Bristol F. \& Card C.E. 1996. Risk factors associated with the incidence of foal mortality in an extensively managed mare herd. Can. Vet. J. 37(2):91-95. PMid:8640655.

Hammer C.J., Booth J.A., Etzel L. \& Tyler H.D. 2001. Adequacy of a concentrated equine serum product in preventing failure of immune passive transfer in neonatal foals: preliminary study. Equine Vet. J. 33(7):734-736. http:// dx.doi.org/10.2746/042516401776249345. PMid:11770999.

Hammer C.J., Tyler H.D. \& Miller P.A. 2000. Effects of oral administration of concentrated equine serum IgG to newborn foals on passive immunity. J. Equine Vet. Sci. 20(5):337-338. http://dx.doi.org/10.1016/S07370806(00)70422-9.

Hardefeldt L.Y., Keuler N. \& Peek S.F. 2010. Incidence of transfusion reactions to commercial equine plasma. J. Vet. Emerg. Crit. Care 20(4):421-425. http://dx.doi.org/10.1111/j.1476-4431.2010.00545.x. PMid:20731808.

Higuchi T., Arakawa T., Hashikura S., Inui T., Senba H. \& Takai S. 1999. Effect of prophylactic administration of hyperimmune plasma to prevent Rhodococcus equi infection on foals from endemically affected farms. J. Vet. Med. 46(9):641-648. http://dx.doi.org/10.1046/j.1439-0450.1999.00284.x. PMid:10605374.

Hofsaess F.R. 2001. Time of antibody absorption in neonatal foals. J. Equine Vet. Sci. 21(4):158-159. http://dx.doi.org/10.1016/S0737-0806(01)70119-0.

Hurcombe S.D., Mudge M.C. \& Hinchcliff K.W. 2007. Clinical and clinicopathologic variables in adult horses receiving blood transfusions: 31 cases (19992005). J. Am. Vet. Med. Assoc. 231(2):267-274. http://dx.doi.org/10.2460/ javma.231.2.267. PMid:17630896.

Hurcombe S.D.A., Matthews A.L., Scott V.H.L., Williams J.M., Kohn C.W. \& Toribio R.E. 2012. Serum protein concentrations as predictors of serum immunoglobulin G concentration in neonatal foals. J. Vet. Emerg. Crit. Care 22(5):573-579. http://dx.doi.org/10.1111/j.1476-4431.2012.00794.x. PMid:23110570.

Jacobsen S. \& Andersen P.H. 2010. The acute phase protein serum amyloid A (SAA) as a marker of inflammation in horses. Equine Vet. Educ. 19(1):3846. http://dx.doi.org/10.1111/j.2042-3292.2007.tb00550.x.

Jeffcott L.B. 1974a. Some practical aspects of the transfer of passive immunity to newborn foals. Equine Vet. J. 6(3):109-115. http://dx.doi. org/10.1111/j.2042-3306.1974.tb03942.x. PMid:4137197.

Jeffcott L.B. 1974b. Studies on passive immunity in the foal. 1. Gamma-globulin and antibody variations associated with the maternal transfer of immunity 
and the onset of active immunity. J. Comp. Pathol. 84(1):93-101. http:// dx.doi.org/10.1016/0021-9975(74)90031-0. PMid:4137211.

Kaneko J.J., Harvey J.W. \& Bruss M.L. 2008. Clinical Biochemistry of Domestic Animals. 6th ed. Elsevier Inc., Burlington, MA, p.117-172.

Kohn C.W., Knight D., Hueston W., Jacobs R. \& Reed S.M. 1989. Colostral and serum IgG, IgA, and IgM concentrations in Standardbred mares and their foals at parturition. J. Am. Vet. Med. Assoc. 195(1):64-68. PMid:2759897.

Korosue K., Murase H., Sato F., Ishimaru M., Kotoyori Y. \& Nambo Y. 2012. Correlation of serum IgG concentration in foals and refractometry index of the dam's pre- and post-parturient colostrums: an assessment for failure of passive transfer in foals. J. Vet. Med. Sci. 74(11):1387-1395. http:// dx.doi.org/10.1292/jvms.11-0470. PMid:22785030.

Kurtz Filho M., Deprá N.M., Alda J.L., Castro I.N., Corte F.D. \& Silva C.A.M. 1997. Parâmetros fisiológicos e etológicos do potro recém-nascido, na raça puro-sangue de corrida. Braz. J. Vet. Res. Anim. Sci. 34(2):103-108. http://dx.doi.org/10.11606/issn.2318-3659.v34i2p103-108.

Lang A., Souza M.V., Salcedo J.H.P., Sossai S., Araújo R.R., Lourenço G.G. \& Maia L. 2007. Imunidade passiva em eqüinos: comparação entre a concentração de IgG do soro materno, colostro e soro do neonato. Revta Ceres 54(315):405-411.

LeBlanc M.M., McLaurin B.I. \& Boswell R. 1986. Relationships among serum immunoglobulin concentration in foals, colostral specific gravity, and colostral immunoglobulin concentration. J. Am. Vet. Med. Assoc. 189(1):5760. PMid:3733502.

LeBlanc M.M., Tran T., Baldwin J.L. \& Pritchard E.L. 1992. Factors that influence passive transfer of immunoglobulins in foals. J. Am. Vet. Med. Assoc. 200(2):179-183. PMid:1559872.

Liepman R.S., Dembek K.A., Slovis N.M., Reed S.M. \& Toribio R.E. 2015. Validation of IgG cut-off values and their association with survival in neonatal foals. Equine Vet. J. 47(5):526-530. http://dx.doi.org/10.1111/ evj.12428. PMid:25683641.

Martins C.B., Silva M.A.G., Duarte C.A., Albernaz R.M., Lacerda Neto J.C. \& Machado R.Z. 2010. Detecção de anticorpos anti-Rhodococcus equi Em éguas vacinadas e potros pelo ensaio imunoenzimático indireto. Ciênc. Anim. Bras. 11(1):194-200. http://dx.doi.org/10.5216/cab.v11i1.5207.

McClure J.T., Deluca J.L., Lunn D.P. \& Miller J. 2001. Evaluation of IgG concentration and IgG subisotypes in foals with complete or partial failure of passive transfer after administration of intravenous serum or plasma. Equine Vet. J. 33(7):681-686. http://dx.doi.org/10.2746/042516401776249273. PMid:11770990.

McClure J.T., Miller J. \& DeLuca J.L. 2003. Comparison of two ELISA screening tests and a non-commercial glutaraldehyde coagulation screening test for the detection of failure of passive transfer in neonatal foals. Proceedings 49th AAEP Annual Convention, New Orleans, Louisiana, p. 301-305. (Resumo)

McDonald T.L., Larson M.A., Mack D.R. \& Weber A. 2001. Elevated extrahepatic expression and secretion of mammary-associated serum amyloid A3 (M-SAA3) into colostrums. Vet. Immunol. Immunopathol. 83(3/4):203-211. http://dx.doi.org/10.1016/S0165-2427(01)00380-4. PMid:11730930.

McTaggart C., Penhale J. \& Raidala S.L. 2005. Effect of plasma transfusion on neutrophil function in healthy and septic foals. Aust. Vet. J. 83(8):499-505. http://dx.doi.org/10.1111/j.1751-0813.2005.tb13304.x. PMid:16119424.

Metzger N., Hinchcliff K.W., Hardy J., Schwarzwald C.C. \& Wittum T. 2006. Usefulness of a commercial equine IgG test and serum protein concentration as indicators of failure of transfer of passive immunity in hospitalized foals. J. Vet. Intern. Med. 20(2):382-387. http://dx.doi.org/10.1111/j.1939-1676.2006. tb02872.x. PMid:16594598.

Murata H., Shimada N. \& Yoshioka M. 2004. Current research on acute phase proteins in veterinary diagnosis: an overview. Vet. J. 168(1):28-40. http:// dx.doi.org/10.1016/S1090-0233(03)00119-9. PMid:15158206.

Naoum P.C. 1999. Eletroforese: técnicas e diagnósticos. $2^{\underline{a}}$ ed. Santos Livraria e Editora, São Paulo, p.1-38.
OIE 2014. Validation Guideline 3.6.1 Development and Optimisation of Antibody Detection Assays. World Organization for Animal Health, Paris. Disponível em <http://www.oie.int/fileadmin/Home/eng/Health_standards/ tahm/GUIDELINE_3.6.1_ANTIBODY_DETECT.pdf> Acesso em 20 jan. 2015.

Paltrinieri S., Giordano A., Villani M., Manfrin M., Panzani S. \& Veronesi M.C. 2008. Influence of age and foaling on plasma protein electrophoresis and serum amyloid $A$ and their possible role as markers of equine neonatal septicaemia. Vet. J. 176(3):393-396. http://dx.doi.org/10.1016/j. tvjl.2007.05.018. PMid:17644376.

Paradis M.R. 2006. Equine Neonatology: A Case-Based Approach. Elsevier Inc., Philadelphia, PA. 287p.

Pusterla N., Berger Pusterla J., Spier S.J., Watson J.L. \& Puget B. 2002. Evaluation of the SNAP foal IgG test for the semiquantitative measurement of immunoglobulin G in foals. Vet. Rec. 151(9):258-260. http://dx.doi. org/10.1136/vr.151.9.258. PMid:12233826.

Raidal S.L., McTaggart C. \& Penhale J. 2005. Effect of withholding macromolecules on the duration of intestinal permeability to colostral IgG in foals. Aust. Vet. J. 83(1):78-81. http://dx.doi.org/10.1111/j.1751-0813.2005.tb12202.x. PMid:15971825.

Riond B., Wenger-Riggenbach B., Hofmann-Lehmann R. \& Lutz H. 2009. Serum protein concentrations from clinically healthy horses determined by agarose gel electrophoresis. Vet. Clin. Pathol. 38(1):73-77. http://dx.doi. org/10.1111/j.1939-165X.2008.00100.x. PMid:19171019.

Scotoni C.M.M. \& Machado Neto R. 1991. Transferência de imunidade passiva em equinos: comportamento imunológico do recém nascido. Anais da Escola Superior de Agricultura Luiz de Queiroz 48(0):109-126. http:// dx.doi.org/10.1590/S0071-12761991000100007.

Sedlinská M., Krejčí J., Vyskočil M. \& Kudláčková H. 2006. Postnatal development of blood serum concentrations of immunoglobulin IgG, IgA and IgM isotypes in suckling foal. Acta Vet. Brno 75(2):175-182. http:// dx.doi.org/10.2754/avb200675020175.

Sheoran A.S., Timoney J.F., Holmes M., Karzenski S.S. \& Crisman M.V. 2000. Immunoglobulin isotypes in sera and nasal mucosal secretions and their neonatal transfer and distribution in horses. Am. J. Vet. Res. 61(9):10991105. http://dx.doi.org/10.2460/ajvr.2000.61.1099. PMid:10976743.

Smith P.K., Krohn R.I., Hermanson G.T., Mallia A.K., Gartner F.H., Provenzano M.D., Fujimoto E.K., Goeke N.M., Olson B.J. \& Klenk D.C. 1985. Measurement of protein using bicinchoninic acid. Anal. Biochem. 150(1):76-85. http:// dx.doi.org/10.1016/0003-2697(85)90442-7. PMid:3843705.

Tietz N.W. 2008. Fundamentals of Clinical Chemistry. 6th ed. Saunders, Toronto, p.212-298.

Tizard I.R. 2004. Veterinary Immunology an Introducion. 7th ed. Saunders, Philadelphia, PA. 494p.

Tscheschlok L., Venner M. \& Howard J. 2017. Comparison of IgG concentrations by radial immunodiffusion, electrophoretic gamma globulin concentrations and total globulins in neonatal foals. Equine Vet. J. 49(2):149-154. http:// dx.doi.org/10.1111/evj.12575. PMid:27037614.

Tyler-McGowan C.M., Hodgson J. \& Hodgson D. 1997. Failure of passive transfer in foals: incidence and outcome on four studs in New South Wales. Aust. Vet. J. 75(1):56-59. http://dx.doi.org/10.1111/j.1751-0813.1997. tb13832.x. PMid:9034501.

Waelchli R.O., Hässig M., Eggenberger E. \& Nussbaumer M. 1990. Relationships of total protein, specific gravity, viscosity, refractive index and latex agglutination to immunoglobulin G concentration in mare colostrum. Equine Vet. J. 22(1):39-42. http://dx.doi.org/10.1111/j.2042-3306.1990. tb04203.x. PMid:2105210.

Wilson E.M., Holcombe S.J., Lamar A., Hauptman J.G. \& Brooks M.B. 2009. Incidence of Transfusion Reactions and Retention of Procoagulant and Anticoagulant Factor Activities in Equine Plasma. J. Vet. Intern. Med. 23(2):323-328. http://dx.doi.org/10.1111/j.1939-1676.2008.0254.x. PMid:19192141. 